The International Journal of Indian Psychology

ISSN 2348-5396 (e) | ISSN: 2349-3429 (p)

Volume 5, Issue 1, DIP: 18.01.105/20170501

DOI: $10.25215 / 0501.105$

http://www.ijip.in | October-December, 2017

Original Research Paper

\title{
Emotional Intelligence of Higher Secondary School Students With Respect to Their Gender
}

\author{
Arshad Ali Bhat ${ }^{1 *}$
}

\section{ABSTRACT}

Present Study lights on Emotional Intelligence in higher secondary school students. Emotional intelligence is the ability to understand emotional intelligence and their causes, the capability to effectively regulate these emotions in one self and in others and most importantly being able to use the emotions as a source of and dealing with social situations. The sample of present study was drawn randomly from different higher secondary schools, of baramulla district state Jammu and Kashmir. The researcher therefore selected 11th \& 12th grade 120 students randomly from different higher secondary schools of baramulla district, out of 120 students 60 were girls and 60 were boys. The investigator has employed English version of Emotional Intelligence scale (EIS) as developed by Anukool Hyde, Sanjyot Pethe And Upinder Dhar is used for the present study. The scale is based on five dimensions viz. self awareness, empathy, self motivation, emotional stability, managing relations, integrity, self development, value orientation, commitment, altruistic behavior. There is significant difference between boys and girls in the level of emotional intelligence.

\section{Keywords: Emotional Intelligence, School, Students, Gender}

In today's modern era life is changing very rapidly. In this situation our adolescent facing a lots of challenges and adjustment problems at home , on work place in social relationship and other areas of his life. Many times it happened due to lack of self- awareness, self-regulation and social skills. These all are component of emotional intelligence. Goleman (1995) found in his study emotional intelligence has five components which are self-awareness, selfregulation, motivation, empathy and social skills. Emotional intelligence is one of the important areas of modern stress management. It is one of the recent fascinating concepts that are essential for success in life. Mayer, Salovey, and Caruso (2000) suggested that emotional intelligence is a set of abilities that accounts for how a more accurate understanding of emotions often helps people solve problems in their emotional lives. They defined emotional intelligence as "the ability to perceive and express emotion, assimilate emotion in thought, understand and reason with emotion, and regulate emotion in the self and others”. EQ enthusiasts believe those who achieve academically, yet have not developed their emotional

\footnotetext{
${ }^{1}$ Govt. women's college, M A Road Srinager, Jammu and Kashmir, India

*Responding Author

(C) 2017 Bhat A A; licensee IJIP. This is an Open Access Research distributed under the terms of the Creative Commons Attribution License (www.creativecommons.org/licenses/by/2.0), which permits unrestricted use, distribution, and reproduction in any Medium, provided the original work is properly cited.
} 
intelligence, and are not likely able to achieve their full capacity. Most students will not learn well if they are not engaged and if their emotions, learning styles, personality, and motivation are not considered. Teachers are responsible to provide an environment conducive to learning and the best instruction possible. On a continuum, process is at least as important as content, so schools should address the whole child, and education should expand beyond the school walls into the community. The stated goals of schools today should not only be to help students achieve academically, but also to understand and manage their emotions and become productive, well-adjusted citizens. Peter Salovey and John Mayer (1990) firstly coined the term emotional intelligence. According to Singh (2003) today only IQ is not sufficient for success but it is the EQ that matters most. Goleman $(1995,1998)$ defined Emotional intelligence as "the composite set of capabilities that enable a person to manage him/her and others.” It is believed that emotional intelligence plays a very important role in leadership, work life and career development. IQ predicts only about 20 percent of career success, which leave the remaining 80 percent to other factor such as emotion intelligence (Pool 1997). This is the reason for why some boys and girls have high level on IQ but they are not successful in his life. Barons (1988) define emotional intelligence as "the ability to: Emotional Intelligence is one of the best predictors of success in life. Emotionally Intelligent people are more likely to success in everything they undertake in life. Emotional intelligence is as powerful \& at time more powerful then I.Q., while I.Q. contributes only to about $20 \%$ of success in life, Emotional intelligence, luck and social class are among other forces, which contribute the rest. We can teach and improve Emotional Competencies in students, paving the way for increasing their Emotional Intelligence and thus making their life more healthy enjoyable and successful in coming days. Emotional intelligence essentially reflects one's ability to deal successfully with other people and with their own feeling. Since these qualities count significantly towards persons success in the area of achievement it may induce him like wise to achieve the required success most of the problem in our life. Whether childhood problems, adolescent problem, home problem, family adjustment are the result of misinterpretation of involved sentiment, feeling and emotions of concerned individual society and the nation. Teacher should make efforts for training the emotions and developing proper Emotional Intelligence understanding, empathy accompanied with right action and behavior on the part of the individual and group to lead a better life in peace and cooperation.

1) Be aware to understand and to express oneself.

2) Be aware of, to understand,

3) to control one's impulse and

4) Adopt to change and to solve problems of a personal or a social nature.

Many educators and psychologists believe that students who receive an exclusively academic environment may be ill equipped for future challenges, both as individuals as well as members of the society. Certain instances come in our day to day life wherein the brightest students in a class did not succeed later in their lives as individuals having well rounded personalities as compared to their less intellectual counterparts. These examples are particularly evident in various fields like politics, business and administration (Singh, 2002). 
But then a question arises what is it that helps a person to succeed in life other than intelligence? Which human quality is it that helps people to function better in all spheres from career to personal life? With the dawn of 21st century, the human mind added a new dimension which is now being held responsible more for success than intelligence. This is termed as Emotional Intelligence and is measured as EQ (Emotional Quotient). Concept of Emotional Intelligence- Over the past several years the term emotional intelligence has received much attention as a factor that is useful in understanding and predicting individual's performance at work, at home, at school etc. The concept of Emotional Intelligence was first introduced by Salovey and Mayer in the early $1990^{\circ e}$ s and made popular by Daniel Goleman with publication of his book: "Why it can matter more than IQ" in 1995. Emotional intelligence is the capacity to create positive outcomes in relationships with others and with oneself. According to Mayer and Salovey (1993), emotional intelligence is the ability to monitor one's own and others "e feelings and emotions, to discriminate among them, and to use this information to guide one's thinking and actions. Thus, emotional intelligence is an umbrella term that captures a broad collection of interpersonal and intrapersonal skills. Interpersonal skills consist of the ability to understand the feelings of others, empathies, maintain and develop interpersonal relationships and above all our sense of social responsibility. On the other hand, intrapersonal skills comprise of the ability to understand one's own motivation. Emotional intelligence plays a key role in determining life success.

\section{Components of Emotional Intelligence:}

According to Dunn (2003), components of emotional intelligence which can regarded as key to success in life are as follows: Self-awareness and self -honesty, Knowledge about cause of emotions, Empathy, Motivation and good decision -making, Ability to analyze and understand relationships, Intuitiveness, Creative and flexible thinking, Integrated self and balance life. We can say emotional intelligence plays a key role in determining life success. It becomes more and more important people progress up the career ladder of their life. So that's reason over the past several year the Emotional intelligence has received much attention as a factor that is useful in understanding and predicting individual's performance at work, at home, at school etc. Chu (2002) reveled that males have high level of emotional intelligence than that of females. The probable reason for the present finding might be due to the fact that emotional intelligence primarily deals with managing and expressing once emotions as well as social skills. And S.Katayal and E.Awarthi (2005) found in his study girls had higher emotional intelligence than boys. Study was done in Chandigarh among adolescent boys and girls studying in $\mathrm{X}^{\text {th }}$ class. Brody \&Hall (1993) in his study suggested that women's greater ability to feel a wide range of emotions with more intensity and variability than men. Topia (1999) and Dunn (2002) observed that girls score higher with regard to empathy, social responsibilities and interpersonal relationship than boys. More sensitivity was found towards their relationship with parents, friends and sib lings. All these traits help them to acquire more emotional intelligence as compared to boys. Emotional intelligence is the latest development in understanding the relationship between thought and emotion. The term was first proposed by Salvi and Meyer. It means a capacity to perceive, express, recognize, use and manage one's emotions, and others (Meyer \& Salvi, 1997). 


\section{Emotional Intelligence of Higher Secondary School Students With Respect to Their Gender}

According to Bar-on, Emotional intelligence is a set of non-cognitive capabilities, competencies and skills that affect the individual's ability to be successful, cope with the environmental demands and pressures (Han, 2000).

The theory of emotional intelligence is a new perspective in predicting the factors affecting success and also provides the primary prevention of mental disorders that complement the cognitive sciences and the child's growth. Emotional intelligence competencies have much more importance in the emotional self-regulation and skillfully management (Bar-on, 1999). Only general intelligence is not sufficient to explain the success and the research show that general intelligence at best explains only $25 \%$ of success and the rest depends on emotional social Intelligence (Goleman, 1995). According to the traditional definition, intelligence has long been considered as the main factor in academic achievement and success, but now with the changing in the theoretical views about the factors forming intelligence, it is no longer considered as successful predictor of academic achievement. At best, intelligence contributes about 20\% in predicting success in life. Herrnstein and Murray, in their book called "the bell curve" gave the highest importance to the intelligence. They believe that characteristics that a person achieves in life overshadow the relationship between test results and progress. Gardner also believes that it is not a unified and integrated intelligence that guarantees success in life, but there is also a wide range of intelligence that lead to the success of individuals in different areas. Thus knowing that a person is privileged graduates, only means that he has been very successful in the aspects measured by the score, while it does not tell us anything about this fact that how he will react to the ups and downs of life. There is a problem in our educational system that its emphasis is purely on academic ability and the emotional intelligence, a set of traits that are important to the fate of individuals, are ignored because social and emotional abilities and competencies are considered as influencing factors in academic achievement. Today the assessment of emotional intelligence and its effects on the academic achievement is the most important areas of research in psychology. The question is that what capabilities are needed to achieve success? Is the presence of a strong scientific mind equal to academic success? Today the researchers, by the help of emotional intelligence and social theory, seek to explain the educational and career success (Bar- on, 2000). According to some researchers, determinants of academic achievement include intelligence, family environment, and parental educational level, the relationship between patterns, motivation, self-concept and psychological adaptation. The relationship between emotional intelligence and academic achievement and gender of students has been assessed in different studies. Some researchers believe that in new researches what is rejected is not the relationship between intelligence and academic achievement, but more emphasis on the differences such as openness to the experiences, introversion extraversion, conscience, agreement, and emotional stability. In this way the research of Nayser and his colleagues suggest that the scores of people in IQ tests can not be a good predictor for the academic achievement. In addition, Leif in a research on emotional intelligence and academic achievement concluded that general intelligence explain only 50 percent of academic achievement. Studies indicate the importance and role of emotional intelligence in various aspects of life, such as education, occupation and education. Sternberg and Wagner, in a 
study on 286 college students, called "the relationship between emotional intelligence and indicators of academic performance and compliance with university”, found a significant correlation. American Psychiatric Association studied the patterns of success and emotional development among academic successful women in deprived class. In this study, the experiences of 21 women (24-54 years old), who were successful in school, were studied. The results also showed that people with higher emotional intelligence have better academic achievement. Elias and his colleagues in a series of studies found that emotional skills can have long-term effects on academic achievement. Parker and his colleagues (2004) in a study "the relationship between emotional intelligence and academic achievement of high school students" found that there is a strong relationship between some aspects of emotional intelligence and academic achievement (mean score). Pe trides and his colleagues in a study "the role of emotional intelligence in academic performance" indicated that emotional intelligence is important in various aspects of life, such as education, occupation and social environment, while our educational system still emphasizes on IQ and its effect on different aspects of life. Therefore, conducting such studies in order to persuade the educational authorities to pay attention to EQ as a critical component for the students' performance seems necessary (Bar- on, 2000). To feel good about oneself, experience one's emotions directly, and grow emotionally”, to be the most urgent need of mankind (Herman, 1992). Emotion refers to a feeling with its distinctive thoughts, psychological and biological states and ranges, and propensity to act. Emotion, an important factor for cognitive functioning has been ignored by the cognitive psychologists in the early stages; it was believed that its inclusion would unnecessarily complicate the cognitive scientific enterprise,(Gardner, 1985). Later, it was recognized that 'emotion' and 'cognition' are integral and inseparable parts of each other and, though it is useful to use different names for different aspects of mentation, the parts are no more separable than are waves from the water on which they occur." (Power and Dalgleish, 1997).

LeDoux (1992, 1996), has shown the existence of a fast, non-conscious emotion circuit and a slow, cortical emotion circuit. There is experimental support to believe memory is best when the learner perceives that his or her mood state has been caused by the learning material (Eich, Metcalfe, 1989).Some researchers (e.g., Smith \& Lazarus, 1993) have studied the effects of cognition on emotion, claimed that some cognitive processing is an essential prerequisite for an effective reaction to a stimulus to occur. Cognitive appraisal underlies and is an integral feature of all emotional stages (Lazarus, 1982). In short, there is reasonable support for the claims that emotional processing depends interactively on personality and mood states (Power \& Dalgleish, T, 1997; Rusting, C.L., 1998). Convincing evidences from the research findings of cognitive psychologists who were studying the relationship between cognition and emotion have led to development of a novel concept 'Emotional Intelligence'. Emotional intelligence has been a source of concern and research towards the end of the $20^{\text {th }}$ century. It refers to the capacity for recognizing our own feelings and those of others, for motivating ourselves and for managing emotions well in ourselves and in our relationships (Daniel Goleman, 1998). According to the proponents of emotional intelligence (EI), a person's emotional make-up largely determines his or her professional success. They believe 
that EI is the most important determinant of the extent of professional and personal success in life. According to Goleman, (1998), 80\% of a person's success in life depends on a person's emotional intelligence, and only about 20\% depends on IQ. "Emotional Intelligence involves the ability to perceive accurately, appraise, and express emotion; the ability to access and / or generate feelings when they facilitate thought; the ability to understand emotion and emotional knowledge; and the ability to regulate emotions to promote emotional and intellectual growth” Mayer and Salovey (1997). According to Herrnstein and Murray (1994), people are normally distributed in intelligence; poverty and unemployment, to some extent, is the effect of low general intelligence, and, affluence is associated with high general intelligence. Daniel Goleman (1995) countered this impression by introducing the concept 'Emotional intelligence' and stated that “it (EI) can be as powerful, and at times more powerful, than IQ”. EI includes components like self-awareness, ability to manage moods, motivation, empathy and social skills such as cooperation and leadership (Goleman, 1998 ). When it comes to emotional intelligence neither woman are 'smarter' nor men are 'superior'. Men and women are equal in their ability to increase emotional intelligence; while women tend to be strong in competencies based on empathy and social skills, men do better in those based on self regulation (Goleman, 1998). Whether these findings can be generalized to people of Africa remains an open question. An examination of the North American sample did not reveal significant differences on emotional and social intelligence between the various ethnic groups that were compared, (Suzuki \& Valencia, 1997). Emotional intelligence is a scientific human Endeavour to bridge between two different human conditions of one human body, originating from head and heart respectively. Such collaboration of meaningful human emotions plays a pivotal role in deciding human achievement. Emotional intelligence is a phase that incorporates the intricate aspects of both emotion and intelligence. Emotions rule the heart while intelligence reigns supreme in the brain.

\section{Significance of the study:}

Emotional Intelligence (EI) is considered to be the most important determinant of success in professional and personal life among human beings. EI includes components like selfawareness, Empathy, Self motivation, Emotional stability, Managing relations, Integrity, Self development, Value orientation, Commitment, Altruistic behaviour such as cooperation and leadership (Goleman, 1998).findings from this study will assist researchers, professionals, parents, teachers and clients to gain an increased understanding of the new constructs of emotional ability introduced to the boys and girls of the state Jammu and Kashmir

\section{Objectives}

1. To find out the level of emotional intelligence of higher secondary school students in baramulla.

2. To find out the level of emotional intelligence with respect to their gender. 


\section{Emotional Intelligence of Higher Secondary School Students With Respect to Their Gender}

\section{Hypothesis}

- There is no significant difference between boys and girls in the level of emotional intelligence.

\section{METHOD}

The sample of the present investigation consisted of 120 students belonging to the age range of 13-16 years studying in schools of district baramulla Jammu and Kashmir. Out of the 120 students, 60 were boys and 60 were girls.

\section{Tools:}

Emotional Intelligence scale (EIS) as developed by Anukool Hyde, Sanjyot Pethe And Upinder Dhar is used for the present study. The scale is based on five dimensions viz. self awareness, empathy, self motivation, emotional stability, managing relations, integrity, self development, value orientation, commitment, altruistic behavior. This is a five point scale consists of 34 items and each dimension is coded with specific alphabet. The reliability of the scale is 0.88 on 200 sample and validity is 0.93 .

\section{ANALYSIS, RESULTS AND INTERPRETATION:}

The obtained data were subjected to Statistical Analysis such as Mean’s, SDs, and Analysis of Variance, to test the Hypotheses.

Table 1: Shows Means scores, Standard deviations and significance on emotional intelligence:

\begin{tabular}{|l|l|l|l|l|l|}
\hline Variable & Gender & Mean & SD & t value & significance \\
\hline $\begin{array}{l}\text { emotional } \\
\text { intelligence }\end{array}$ & Boys & 120.80 & 12.20 & \multirow{2}{*}{$2.57^{* *}$} & \multirow{2}{*}{ significant } \\
\cline { 2 - 4 } & Girls & 128.01 & 8.93 & & \\
\hline
\end{tabular}

Significant at 0.05 level $^{* *}$

Figure 1: Illustrate and compare emotional intelligence among boys and girls studied in higher secondary schools.

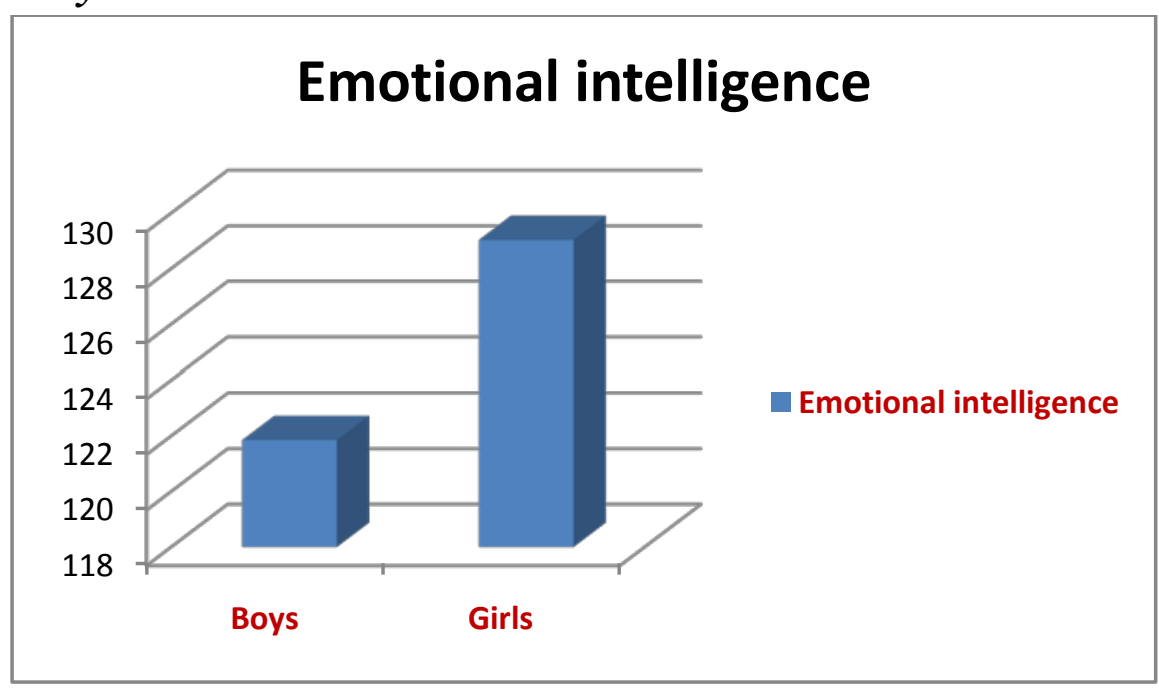

(C) The International Journal of Indian Psychology, ISSN 2348-5396 (e)| ISSN: 2349-3429 (p) | 43 


\section{DISCUSSION \& CONCLUSION}

The hypothesis predicted that "there would be significant impact of Gender on emotional intelligence among boys and girls”. Hence, the hypothesis- 1 is accepted as warranted by the results. The results of the present study consistent with earlier study of Ajay Kumar Bhimrao Patil (2006) revealed that there is significant difference between emotional intelligence of boys and girls student. It is observed from the above table that the, $\mathrm{t}^{\mathrm{ec}}$ value of 2.57 was found significant even at 0.05 level. Therefore, it can be concluded that the H01 "Secondary school boys and girls differ significantly on emotional intelligence” is accepted. In other words, it is implied that secondary school boys and girls differ significantly on emotional intelligence. The obtained results are in line with the findings of studies reported by Bhosle (1999), King (1999), Sutarso (1999), Wing and Love (2001) and Singh (2002). They all found females to have higher emotional intelligence than that of males.

The probable reason for the present findings might be due to the fact that emotional intelligence primarily deals with managing and expressing one's emotions as well as social skills. Since females tend to be more emotional and intimate in relationships as compared to males, so their emotional intelligence ought to be higher than that of males. This is perhaps because of the society, which socializes the two genders differently as has been found in studies by Duckelt and Raffalli (1989) and Sandhu and Mehrotra (1999). Moreover, higher emotional intelligence among girls can also be explained in terms of some of their personality characteristics. Similar findings were reported in studies by Tapia (1999) and Dunn (2002). They observed that girls score higher with regard to empathy, social responsibilities and interpersonal relationships than boys. They are more sensitive towards their relationships with parents, friends and siblings. All these traits help them to acquire more emotional intelligence as compared to boys. This study is only a stepping stone in the field of emotional intelligence. This aspect requires much more exploration as there is dearth of research work, especially in India. Findings of this research study will prove beneficial for educators, parents, counsellors etc. for providing better knowledge about this vital component of success and its important predictors. An understanding of all these aspects will provide a better insight into the success equation required in life. It is concluded that the findings of this study revealed that girls have more emotional intelligence rather than boys who studied in different higher secondary schools in district baramulla state Jammu and Kashmir.

\section{Delimitations}

- $\quad$ The present study have consists only 120 sample.

- $\quad$ The present study have sample from only baramulla district.

\section{Acknowledgments}

The author appreciates all those who participated in the study and helped to facilitate the research process.

Conflict of Interests: The author declared no conflict of interests. 


\section{REFERENCES}

B.L.Tischler (Ed.), Sights on the Sixties. New Brunswick, NJ: Rutgers University Press.

Dalip Singh (2001). Emotional Intelligence at Work a Professional Guide. Sage Publications:

New Delhi. Dan Connell (2000). Against All Odds, the Read Sea Press, Inc. Asmara, Eritrea,

Das, M.N. \& Ghosh, S. (2014) A comparative account of academic achievement and emotional maturity among secondary school students of rural and urban area. European Academic Research, II(6), 7392-7401

Dubey, R. (2012). Emotional intelligence and academic motivation among adolescents: A relationship study. International Journal of Multidisciplinary Research, Vol.2, Issue 3, pp. 142-147.

Eich,E., \& Metcalfe,J. (1989). Mood dependent memory for internal versus external events. Journal of Experimental Psychology: Learning, Memory,\& Cognition,15,443-455.

Eritrea - Demographic and Health Survey (2002). Asmara, Eritrea: National Statistics and Evaluation Office.

Freud, S., 1995. Family therapy. An Overview, 19. BrOwn, M., 1997. Quality of emotional intelligence. 21(95): 213-237. Psychology J., 38(97): 67-71.

G. Sitarenios, 1997. Emotional intelligence as a Books. World Appl. Sci. J., 15 (4): 555-561, 2011561

Gardner,H (1985). The Mind's New Science. New York: Basic Books.

George, R., and Shari, B. (2012). Role of emotional intelligence on stress and coping of gifted adolescents. International Journal of Physical and Social Sciences, Vol.2, Issue 9, pp. 524-538.

Goelman,D. (1995). Emotional Intelligence. New York: Bantam Books

Goleman, D. (1995). Emotional Intelligence: Why it can matter more than IQ. London: Bloomsbury.

Goleman, D., 1995. Emotional Intelligence (translated Stair, V.M. and M. Baldwin, 1983. Step by step. Palo by Nasrin Parsa). Tehran: Roshd Publications, (2002). Alto. Science and Behavior, 21(83): 98-102. 23. Leeper,M.A., C. Mader, J. Gramzow and K. Papineau,

Goleman, D., 1998. Working with emotional and personality? J. Personality and Individual intelligence. J. Psychosomatic Medicine, Differences, 38(4): 1353-64. 10(98): 24-29.

Goleman,D. (1996). Emotional Intelligence: Why it can Matter more than IQ. New York: Bantam Books.

Goleman,D. (1998). Working with Emotional Intelligence. New York: Bantam Books.

Gornefski, G., 2004. Does emotional intelligence Psychosomatic Medicine, 8(95): 160-168. predict unique variance in life satisfaction beyond IQ.

Gross, J.J. and O.P. John, 1998. Mapping the domain 30. Bar-on, R., 1977. Emotional and social intelligence: of expressivity: Multimethod evidence for a Insights from the emotional quotient inventory. The hierarchical model. J. Personality and Social Psychol., Handbook of Emotional Intelligence, 23(2): 490-504. 74(98): 170-191.

Herman, E. (1992). Being and Doing: Humanistic Psychology and the Spirit of the 1960s. In. 


\section{Emotional Intelligence of Higher Secondary School Students With Respect to Their Gender}

Kafetsios, K., 2010. Attachment and emotional 28. Mayer, J.D., P. Salovey and D.R. Caruso, 2002. intelligence abilities across the life cours. Personality Relation of an ability measure of emotional and Individual Differences. intelligence to personality. J. Personality

Karsini, H., W.D. Allan, J.M. Mayer, M. Werner and 21. Mayer, J.D. and P. Salovey, 1990. What is a J.C. Reid, 1996. An examination of family functioning emotional intelligence? Emotional development and utilizing the circumplex model in psychiatrically emotional intelligence: Implications for educators. hospitalized children with depression. J. Affective New York: Basic Books. Disorders, 35(96): 6573.

Katyal, S., and Awasthi, E. (2005). Gender differences in emotional intelligence among adolescents of Chandigarh. J. Hum. Ecol, Vol. 17, Issue 2, pp. 153-155.

Katzko, 2002. Dose a to Family Psychotherapy. J. Personality and self-report measure for emotional intelligence assess Individual Differences, 34(91): 707-721. something different than general intelligence.

Kaur, M. (2013). A Comparative Study of Emotional Maturity of Senior Secondary School Students. International Indexed, Referred Research Journal, ISSN-2250-2629.

Kring, J.L. and B. Mallinckrodt, 1994. Family Assessment, 79(2): 306-320. environment and alexithymia in clients and 29. Carole, G.L.G., 1993. Family Treatment. J. Efficient nonclients. J. Psychotherapy Res., 10(94): 78-86. Therapy Guarantee, 14(93): 234256.

Lazarus,R.S. (1982). Thoughts on relations between emotion and cognition. American Psychologist,37, 1019-1024.

LeDoux,J .E.(1992). Emotion as memory: Anatomical systems underlying indelible neural traces. In S.A.

LeDoux,J.E (1996). The Emotional Brain: The Mysterious Underpinnings of Emotional life. New York: Simon \& Schuster.

Mangal,S.K.,and Mangal, S.(2004). Manual for Mangal Emotional Intelligence Inventory. Agra: National Psychological Corporation.

Marquez, P.O., Martin, R.P., and Bracket, M. A. (2006). Relating emotional intelligence to social competence and academic achievement in high school students. Psicothema 2006.Vol.18,pp.1.

Marshal, G.R., 1997. Stimulation and Emotion. J. 33. Schutle, Marfe, D. and C. Bolden, 1998. Consultation Personality and Individual Differences, and Psychotherapy Theories. J. Rasa Cultural 12(97): 235-243. Institute, 23(98): 34-56.

Mayer and Salovey (1997) quoted in Reuven Bar-On \& James D.A. Parker (Ed)(2000). The Handbook of Emotional Intelligence. San Franciso:Jossey-Bass,.

Mayer and Salvey (1993). Emotions and emotional intelligence retrieved from www.socialresearchmethods.net/Gallary /Young/emotion.htm.

Mayer, J.D., P. Salovey and D.R. Caruso, 2000. 37. Minuchin S.F.H., 2005. Techniques of Family Emotional intelligence as zeitgeist, as personality and Treatment. Multilingual Matters Limited. as a mental ability. The handbook of emotional. 


\section{Emotional Intelligence of Higher Secondary School Students With Respect to Their Gender}

Nandwana, S., and Joshi, K. (2010). Assessment of Emotional Intelligence of Tribal Adolescents of Udaipur: An Exploratory Study. Stud Tribes Tribals, Vol. 8, Issue 1, pp.37-40 on 24/04/2013.

Paloma Gil-Olarte Marquez., Raquel Palomera Martin and Mare A. Brackett A. (2006). Relating Emotional Intelligence to Social Competence And Academic Achievement in High School Students. Psicothema, 18, 118-123.

Payne,W.L.(1986). A study of Emotion: Developing Emotional Intelligence; Self integration; relating to fear, pain and desire. Dissertation Abstracts International, 47(10), 203A. (University Microfilms No.AAC 8605928).

Perumalil, T.V., (2004). Relationship between Emotional Intelligence and Teaching Competency of High School Teachers. Unpublishished Ph.D. Thesis, Manonmanium Sundaranar University, Tirunelveli, Tamilnadu.

Power,M., \& Dalgleish, T. (1997). Cognition and Emotion: From Order to Disorder. Hove, UK: Psychology Press.

Redzuam, M., and Naghavi, F. (2011). The relationship between gender and emotional intelligence. World Applied Sciences Journal Vol.15, Issue 4, pp. 555-561.

Reuven Bar-On \& James D.A. Parker (Ed)(2000).The Handbook of Emotional Intelligence., San Francisco:Jossey-Bass,

Rusting, C.L. (1998). Personality, mood,and cognitive processing of emotional information: three conceptual frame works. Psychological Bulletin, 124,165-196.

Salguero, J.M., Palomera, R., and Berrocal, P.F. (2010). Perceived emotional intelligence as predictor of psychological adjustment in adolescents: A 1-year prospective on 24/04/2013.

Scharfe, E., 2000. The handbook of as emotional intelligence. Development of emotional expression, understanding and regulation in infants and youth.

Schwartz, R. C. and S.M. Johnson, 2000. Do couple standard intelligence. J. Emotion., 1(97): 232-242. and family therapy have emotional intelligence. J. 17. Saarni, C., 2000. The handbook of emotional Family Process., 39: 29-33. intelligence. Emotional competence: A developmental

Schwartz, R. C. and S.M. Johnson, 2000. Do couple standard intelligence. J. Emotion., 1(97): 232-242. and family therapy have emotional intelligence. J. 17. Saarni, C., 2000. The handbook of emotional Family Process., 39: 29-33. intelligence. Emotional competence: A developmental

Singh, D. (2002). Emotional Intelligence at Work: A Professional Guide. Sage Publications, New Delhi.

Sitarenios, N., 2001. Family management. Family J., 39. Palmer, F., Donaldson. and Stough, 2002. What is 50(1): 47-53. emotional intelligence? Psychol. J., 27(2): 234-256.

Smith,C.A., \& Lazarus,R.S.(1993). Cognition \& Emotion, in Eysenck, M.W., \& Keane,(Ed) Cognitive Psychology : A Sudents’ Hand Book, M.T. Psychology Press, Taylor and Francis Inc.

Stottlemyer, B. G. (2002). An Examination of Emotional Intelligence: Its Relationship to Achievement and the Implications for Education. Retrieved from http://proquest.umi.com 
Suzuki,L.A., \& Valencia,R.R. (1997). Race,ethnicity and measured intelligence. American Psychologist, 52 (10), 1103-1114.

Trinided, H., Johnson, 2002. Emotional competence: intelligence. NJ: Prentice Hall. A Developmental Perspective.

Vijayapriya \& Nellaiyapan, (2012). Examined emotional intelligence in relation to achievement in mathematics among XI standard students in Puducherry. Annamalai Journal of Education Endeavour, 1(3, 4), 23-30. ISSN 2278-9804.

Williams, L.M. and J. Barry, 2003. Do sex differences the life course. J. Personality and Individual in emotionality mediate sex differences in traits of Differences, 14(85): 2329. psychosis-proneness? J. Cognition and Emotion.,

Yongyuan, B., Chaykliang, Y., Laoma, S., \& Mukdacharn. M.(2007). Emotional Intelligence and Personal Factors Related to Academic Achievement of Upper Secondary School Students. Journal of Social Sciences and Humanities, 13(1), 43-58.

How to cite this article: Bhat A A (2017). Emotional Intelligence of Higher Secondary School Students With Respect to Their Gender. International Journal of Indian Psychology, Vol. 5, (1), DIP: 18.01.105/20170501, DOI: 10.25215/0501.105 